\title{
POLYMERIC MATERIALS IN THE PHYSIOLOGICAL ENVIRONMENT
}

\author{
STEPHEN D. BRUCK \\ National Heart and Lung Institute, National Institutes of Health, Bethesda, MD 20014, USA
}

\begin{abstract}
The interactions between natural and synthetic materials and blood components are analyzed with emphasis on the interdependence between biomaterials research and development and ultimate applications. Two new synthetic polymers, perfluorobutyryl ethylcellulose and polyalkylsulfone, that combine desirable blood compatibility and gas-to-blood transfer rates are discussed in terms of their potential usefulness for membrane oxygenators. Among the several hydrogels, polyacrylamide covalently grafted onto segmented polyether-urethane substrates showed essentially no platelet adhesion and adsorbed the least plasma proteins in comparison to other systems. Polymeric composites having stiffness, anisotropies that approximate living tissues, and the ability to culture cells and hence to maintain a living cellular interface between flowing blood and microfiber substrates, are expected to expand the horizons for biomaterials in prosthetic applications.
\end{abstract}

\section{INTRODUCTION}

Biomaterials are materials that can be implanted in the body to provide special prosthetic functions or used in diagnostic, surgical and therapeutic applications without causing adverse effects on blood or other tissues. ${ }^{1}$ Blood compatible materials constitute a significant part of bimaterials and are restricted to applications in which the contacting fluid is blood. Examples are blood oxygenating membranes in artificial lungs, blood storage bags, blood pumps in circulatory assistance devices, membranes for artificial kidney machines, catheters, shunts, cannulae, sutures, and controlled drug release capsules. Blood compatibility is a broad term and has often been misused to denote performance of biomaterials based on a single or a few in vitro tests that frequently ignore the existence of hemorheological parameters. A truly blood compatible material must not adversely interact with blood components to cause clotting of plasma and lead to thrombosis, or cause other adverse toxic and immunological responses, and cancer. Furthermore, the materials must also be able to perform physical functions and hence must be designed to meet these objectives. ${ }^{2-5}$ Although numerous dogmatic attempts have been made to single out one or more parameters such as wettability, critical surface tension, and surface charge, the decisive events that control blood compatibility occur at the molecular level and are significantly controlled by hemorheological factors of the physiological environment. The lack of understanding of these events still hampers progress although semi-empirical approaches, which are often desirable, resulted in the development of a number of materials that contributed significantly to biomedical science and clinical practice.

\section{DISCUSSION}

\section{Interactions of blood components with surfaces}

It is now established that among the initial events that occur when materials contact blood is the very rapid adsorption of plasma protiens. ${ }^{6-8}$ This process seems to be completed in less than $3 \mathrm{sec}$ and effectively influences the subsequent interactions of the formed blood elements, especially the platelets with the proteinated surfaces. This is not to say that platelets cannot interact with "bare" surfaces in the absence of blood, but in the presence of blood they apparently contact an already deposited protein layer or layers. The adsorption of proteins from plasma is influenced by the type of surface, hemorheological parameters, and quite possibly by the large number of small ionic species present in plasma which are expected to arrive at a given surface prior to proteins. In other words, the adsorption of proteins may be mitigated by a number of parameters, including other plasma components. The term "conditioning" or "passivating" layer has

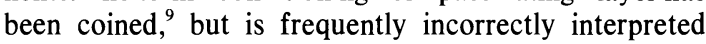
since not all proteinated surfaces remain "passive" toward blood components but, in fact, can result in platelet adhesion, activation and aggregation leading to thrombosis. In reality, the adsorbed proteins do not become permanently immobilized on the surface of a material in the physiological environment. They can be enzymatically degraded, replaced by other proteins, or can undergo various conformational and configurational changes, and denaturation. ${ }^{1,10}$ All these play a dominant role in the activation of plasma coagulation factors, mostly factors XII and XI, and affect the formed blood elements, especially the platelets. When platelets adhere to proteinated surfaces they may become activated depending on the molecular stimuli and hemorheological factors, extrude their granules, liberate adenosine nucleotides, serotonin, and other coagulation activators. ${ }^{11}$ As a consequence, irreversible platelet aggregation results, leading to thrombosis. As indicated schematically in Fig. 1, the process involves at least three major steps: (a) adsorption of and subsequent changes in plasma proteins, (b) clotting of the plasma proteins via a complex series of reactions involving the various clotting factors, and (c) activation of the platelets and their aggregation in conjunction with the other formed blood elements. A thrombus or blood clot represents an interwoven mesh of fibrin (polymerized and crosslinked fibrinogen), platelets, and red and white cells. ${ }^{12}$

The situation is even more complex in the case of natural surfaces. When the endothelial lining of a blood vessel is injured, collagen may become exposed which then promotes the adhesion, activation, and aggregation of the platelets. ${ }^{\text {" }}$ This property of collagen appears to be related to its particular molecular architecture and resultant physiochemical properties. ${ }^{13}$ Under normal conditions, the flowing blood is apparently not in direct contact with endothelial cells which line the blood vessel 
COAGULATION AND THROMBOSIS WHEN FLOWING BLOOD CONTACTS SYNTHETIC SURFACES

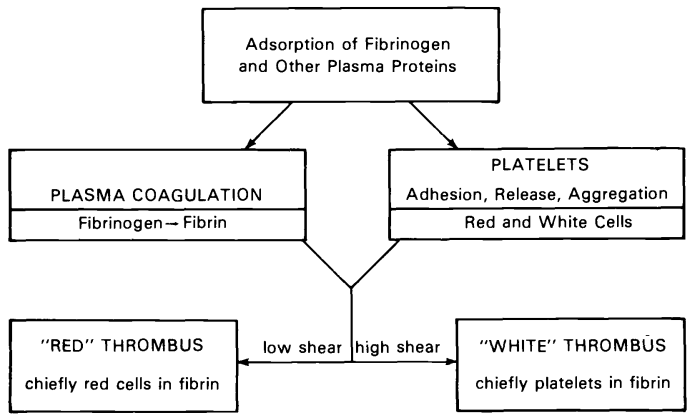

Fig. 1. Coagulation and thrombosis when flowing blood contacts synthetic surfaces.

walls, but with an adsorbed layer of proteins. ${ }^{14}$ The formation of a multilayer of plasma proteins following the initial adsorption of a monolayer could be influenced by changes in the solubility of the proteins, especially fibrinogen, the solubility of which is quite low in plasma. The adsorption process will also be influenced by hemorheological factors. These are often ignored, yet the successful performance of a given material in even the simplest device will be influenced by rheological considerations. Research on the better understanding of the molecular interactions between flowing blood components and materials must proceed in parallel with the development and the physico-chemical and biological testing of biomaterials. Since the surface properties of biomaterials are of great significance, the various steps that lead toward the design of medical devices should insure that these properties are maintained and checked throughout the numerous operations. Figure 2 illustrates the relationship between biomaterials $R \quad \& \quad D$ and applications. It is evident that this represents an interdisciplinary area requiring close collaboration between physical, biological, and medical disciplines.

\section{Biomaterials in blood contacting applications}

Despite the relative ignorance about the molecular and hemorheological events that are involved in blood compatibility, a number of synthetic polymers have been prepared which exhibit little adverse effects on blood components and at the same time retain their physical properties for various periods of time in the physiological environment. These combined biological and physical properties make them useful for various prosthetic and other biomedical applications in surgery and therapy. Research and development on blood compatible materials may be depicted schematically, as shown in Fig. 3, to include studies of : (1) natural macromolecules, (2) synthetic macromolecules (including surface modifications), (3) microfibers (including tissue culture approaches), (4) technology, (5) biological properties, (6) biological testing according to a carefully designed protocol, and (7) physico-chemical properties. Significant practical accomplishments include (a) the development of isotropic (LTI) carbons having the required compatibility with blood and mechanical strength to be useful in thousands of cardiac heart valve replacements $;^{15}$ (b) the heparinization of various polymers by surface treatments, ${ }^{16-20}$ thus making these useful especially in short-term applications such as shunts, catheters, and cannulae; (c) the development of a family of segmented polyether-urethanes especially useful for subsequent surface modifications to enhance their blood compatibility and for various medical devices requiring physical performance, $;^{21-23}$ (d) the development of thin perfluorobutyryl ethylcellulose ${ }^{24}$ and polyalkylsulfone membranes especially useful for blood oxygenators $;^{25}$ (e) the application of glow discharge techniques that enables the surface modification of polymers to impart blood compatibility to them with pure monomers such as silica-free hexamethyldisiloxane and the system of acetylene- $\mathrm{N}_{2}-\mathrm{H}_{2} \mathrm{O} ;{ }^{26,27}$ and (f) the development of blood compatible hydrogels (three-dimensional networks of macromolecules that can imbibe large quantities of water) which can subsequently be grafted onto other polymers to give them proper physical strength. ${ }^{1,29-32}$

Extracorporeal assist devices, such as blood oxygenators, require polymeric membranes having both good blood compatibility and high gas transmission rates toward oxygen and carbon dioxide. Two promising synthetic polymers mentioned above are under investiga-

RELATIONSHIP BETWEEN BIOMATERIALS R \& D AND APPLICATIONS

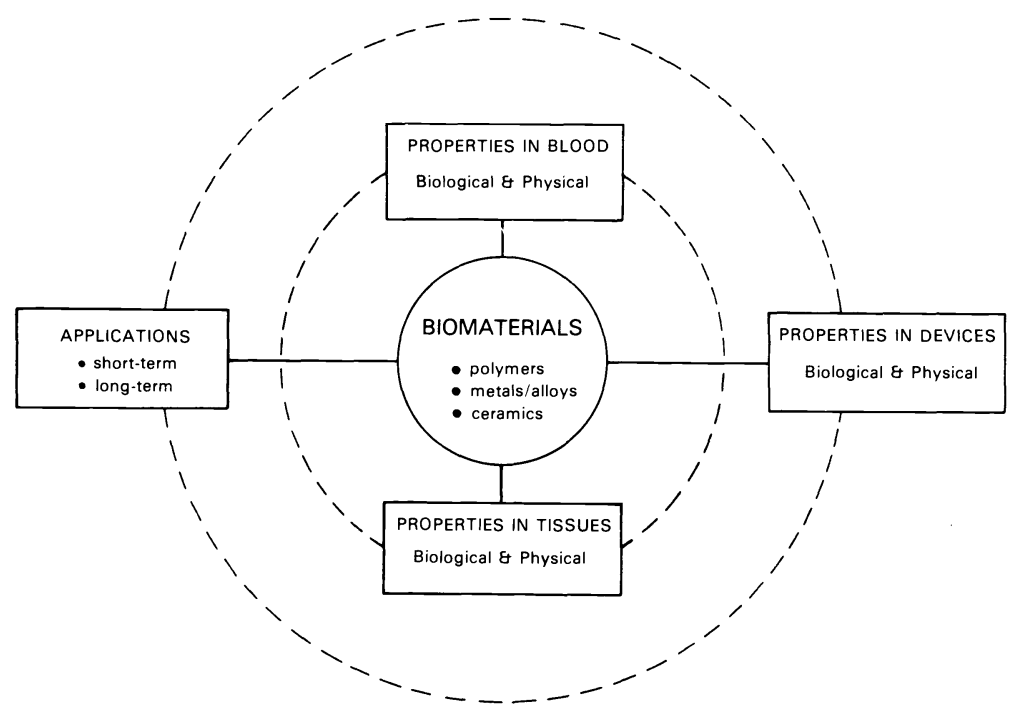

Fig. 2. Relationship between biomaterials R\&D and applications. 


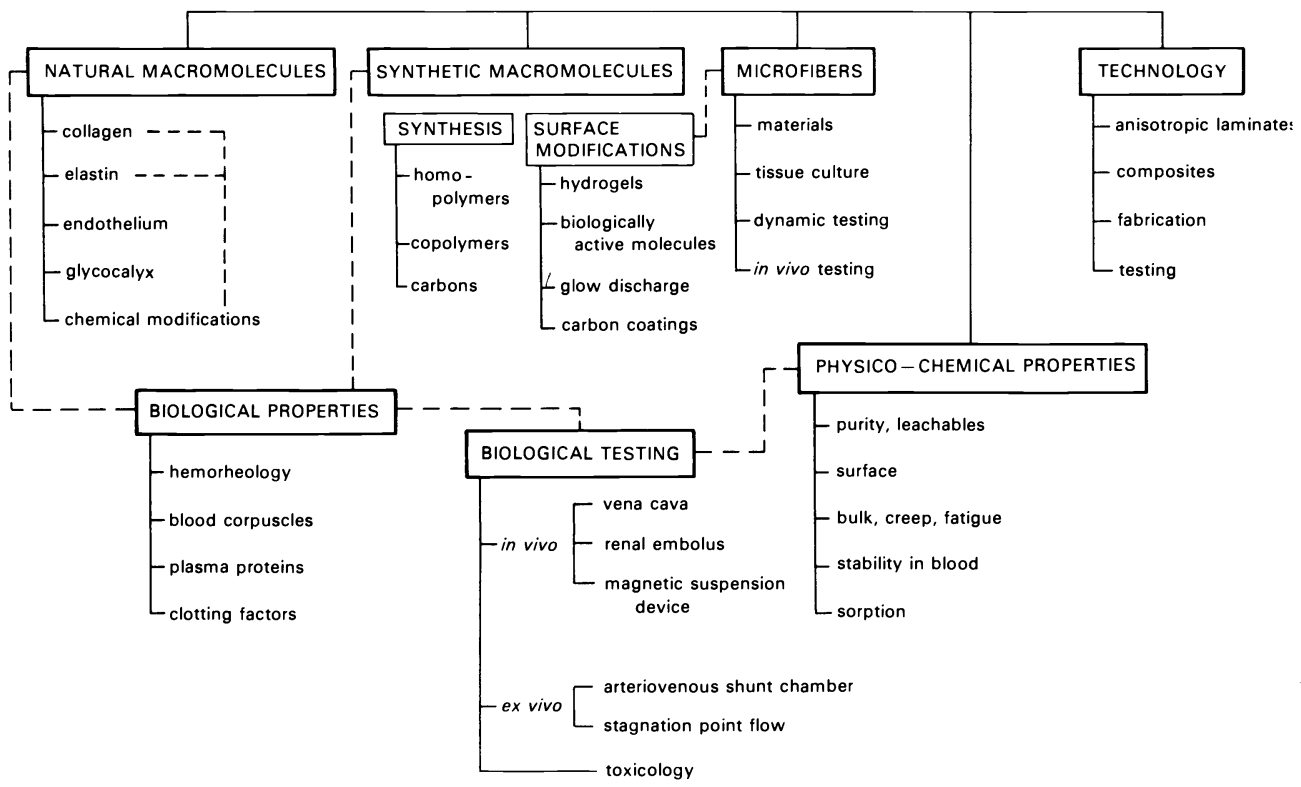

Fig. 3. Blood compatible materials R\&D.

tion, namely perfluorobutyryl ethylcellulose ${ }^{24}$ and polyalkylsulfone, ${ }^{25}$ the chemical structures of which are shown in Figs. 4 and 5, respectively. Although their gas-to-gas permeabilities toward oxygen and carbon dioxide are low in comparison to polydimethylsiloxane, ultra-thin membranes in the range of 1-3 microns can be prepared and laminated to porous polyolefin (such as "Celgard"Celanese) to give the membranes adequate physical support. Such ultra-thin membranes exhibit approximately a four-fold increase in the gas-to-gas transmission rates toward oxygen and carbon dioxide in comparison to polydimethylsiloxane. The gas-to-blood transfer rates toward oxygen are at least as high as those exhibited by

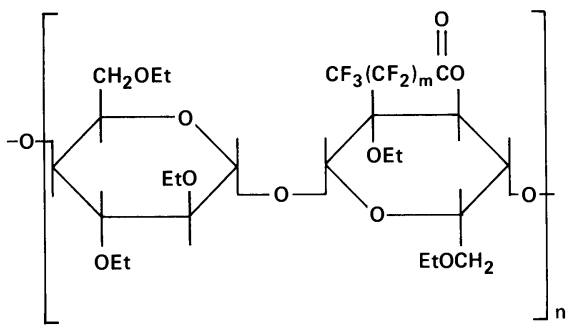

PERFLUOROACYL ETHYLCELLULOSE

Fig. 4. Perfluoroacyl derivatives of ethylcellulose ( $m=4$ denotes perfluorobutyryl ethylcellulose).

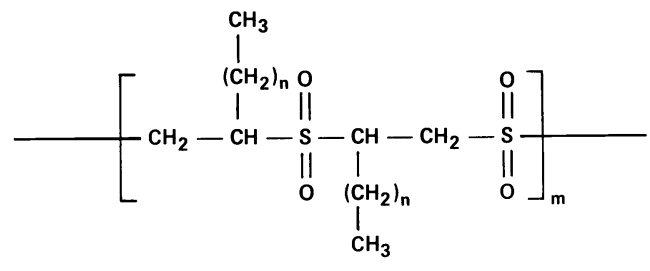

POLYALKYLSULFONE

Fig. 5. Polyalkylsulfone. polydimethylsiloxane under typical clinical flow conditions. Based on the vena cava and renal embolus test systems as well as other biological data, both perfluorobutyryl ethylcellulose and polyalkylsulfone exhibit promising blood compatibility. In fact, the perfluorobutyryl ethylcellulose compares favorably with low temperature isotropic (LTI) carbons (General Atomic Co.). The combination of the promising biological properties and high gas-to-blood transfer rates toward oxygen and carbon dioxide, make these membranes potentially useful candidates for blood oxygenators. This could eliminate the need to use heparinised surface coatings in oxygenator applications to prevent thrombosis. Although it has been shown recently that silica-free polydimethylsiloxane exhibits considerably improved blood compatibility in comparison to the commercial silica reinforced silicone, the above described two synthetic membranes are inexpensive and can be readily prepared and laminated onto porous surfaces without pinholes.

Among other types of materials, covalently grafted hydrogels are useful in a variety of applications, including coatings of catheters, shunts, cannulae, oxygenator membranes, artificial kidney membranes, encapsulants of carbon particles used in hemodialysis in acute hepatic failure and others. As summarized in Table 1, there are essentially three techniques for the covalent grafting of hydrogels to appropriate substrates: (1) chemical (cericion) initiation, (2) microwave discharge, and (3) high energy irradiation $\left({ }^{60} \mathrm{Co}\right.$; Van de Graaf). Preliminary comparative evaluation of one ionic and two non-ionic hydrogels grafted onto polymeric substrates, namely poly(2-hydroxyethylmethacrylate), poly(vinylacetate-co$2 \%$ crotonic acid) $60 \%$ sodium ionomer, and polyacrylamide indicates that ionic groups on the hydrogel are not essential for blood compatibility. The biological performance of the grafted hydrogels seems to be related to the extent of protein adsorption, desorption, and/or conformational and configurational changes, and to the subsequent interactions with blood elements, especially 
Table 1. Hydrogel grafting techniques

Chemical (ceric-ion initiation)

Microwave discharge

High energy irradiation $\left({ }^{60} \mathrm{Co}\right.$; Van de Graaff)

the platelets. These events in turn depend, among others, on the chemical composition, purity, particular preparative conditions, crosslinking density, and the level of water uptake. ${ }^{1,433}$ It should be stressed that the level of water uptake and/or the existence of an organized water structure are insufficient parameters to explain blood compatibility since numerous highly hydrophilic surfaces do not show acceptable biological performance. However, at least in the case of the non-ionic polyacrylamidegrafted hydrogels, it seems that for optimum blood compatibility an equilibrium water uptake of $60-80 \%$ is required prior to implantation, coupled with a low crosslinking density and a graft thickness of about 3$5 \mu \mathrm{m} .{ }^{1,4,33,34}$ The available evidence strongly suggests that for optimum blood compatibility, an equilibrium water uptake approaching the above range is needed also with the two other hydrogel systems. Recent results shown in Tables 2 and 3, respectively, indicate that grafted polyacrylamide elicits no platelet adhesion and adsorbs the least plasma proteins, especially fibrinogen, gammaglobulin, and albumin. ${ }^{35}$ It is interesting that in the case of poly(2-hydroxyethylmethacrylate) the equilibrium water

Table 2. Platelet adhesion from heparinised whole canine blood to polyacrylamide hydrogel covalently grafted onto polyurethane in rotating disc experiments at $400 \mathrm{rpm}$ after $3 \mathrm{~min}$ (data from Ref. 35)*

\begin{tabular}{lc}
\hline & $\frac{\text { Platelet density } / 900 \mu^{2}}{\text { (approximate) }}$ \\
\hline $\begin{array}{l}\text { Non-grafted polyurethane } \dagger \\
\text { Chemically grafted polyacrylamide } \\
\text { with no crosslinker }\end{array}$ & 28 \\
\hline
\end{tabular}

*Data of E. Leonard, S. Kochwa and R. Litwak, Contract NIHNO1-HB-3-2910, Annual Report, January 1975, available from the National Technical Information Service.

$\nmid$ Block polyether-urethane, type 3-1000/425(70/30)-1-X (SRI). uptake is limited to approximately $30-35 \%$ owing to phase separation and can be changed by copolymerization with hydrophilic monomers. These systems have shown applications in soft contact lenses as well as in other areas, and their tissue compatibility has been demonstrated. ${ }^{36,37}$

To estimate the biological performance of biomaterials, in vitro, ex vivo, and in vivo procedures are necessary with suitable animals. It is important to consider any species-related difference, hemodynamic parameters, statistically significant number of tests, and the overall performance of materials in devices. Although there are a number of test procedures under development, the two most widely used in vivo procedures for thrombosis formation have been the vena cava and the renal embolus tests. Table 4 summarizes the in vivo results of selected biomaterials based on these two tests. It should be pointed out that in each case at least six tests were performed on each material. In the case of the vena cava ring tests, the term "excellent" means that there was no or only minimal thrombus formation after 2-hr or 2-weeks, "good" means that at least two-thirds of the rings had either no or only minimal thrombus formation after 2-hr or 2-weeks, and "fair" means that approximately one-half of the rings remained essentially thrombus free after 2-hr or 2-weeks. It should be stressed that both the vena cava and renal embolus test systems should be considered as important, qualitative preliminary indicators of the blood compatibility of candidate materials and must be supplemented by a variety of other tests.

To provide blood compatible surfaces, investigations are also underway to create a viable cellular interface on specially prepared nonwoven microfiber scaffold structures, ${ }^{38}$ and to use denatured tissue components in polymers, so-called "biolized" materials. ${ }^{39}$ In the former approach, blood contacts a living cellular layer rather than the polymer itself, whereas in the latter, the blood contacting interfaces are denatured and crosslinked tissue components.

As it was mentioned above, the application of glow-discharge techniques with pure monomers of hexamethyldisiloxane showed promising blood compatibility based on in vitro and in vivo animal data. ${ }^{27}$ This biological performance is probably related to the absence of silica

Table 3. Uptake of single ${ }^{125}$ I-labeled proteins by hydrogels covalently grafted onto polyurethane in static experiments (data from Ref. 35)

\begin{tabular}{lccc}
\hline & \multicolumn{3}{c}{ Proteins, $\mu \mathrm{g} / \mathrm{cm}^{2}$} \\
\cline { 2 - 4 } & Albumin & Fibrinogen & $\gamma$-Globulin \\
\hline $\begin{array}{l}\text { Non-grafted polyurethane } \dagger \\
\text { Polyurethane chemically } \\
\text { grafted with polyacrylamide } \\
\text { with crosslinker }\end{array}$ & 0.58 & 0.92 & 0.93 \\
$\begin{array}{l}\text { Polyurethane§ chemically } \\
\text { grafted with polyacrylamide } \\
\text { without crosslinker }\end{array}$ & 0.19 & 0.18 & 0.29 \\
$\begin{array}{l}\text { Polyurethane microwave- } \\
\text { discharge grafted with HEMA } \\
\text { with crosslinker\| }\end{array}$ & 0.97 & 0.11 & 0.09 \\
\hline
\end{tabular}

* Data of E. Leonard, S. Kochwa and R. Litwak, Contract NIH-NO1-HB-3-2910, Annual Report, January 1975, available from the National Technical Information Service.

†Block polyether-urethane, type 3-1000/425(70/30)-1-X (SRI).

$\ddagger 2 \% N, N^{\prime}$-methylene-bis-acrylamide.

$\S$ Block polyether-urethane, type 3-2000-1-E (SRI).

$\| 2 \%$ ethylene glycol dimethacrylate crosslinker. 
Table 4. In vivo biological properties of selected biomaterials

\begin{tabular}{|c|c|c|c|c|c|}
\hline & \multicolumn{2}{|c|}{ Vena cava test } & \multicolumn{3}{|c|}{ Renal embolus test } \\
\hline & $2 \mathrm{hr}$ & $2 \mathrm{wk}$ & $\begin{array}{l}\text { Thrombus } \\
\text { on ring }\end{array}$ & $\begin{array}{c}\text { Deposit } \\
\text { below } \\
\text { ring }\end{array}$ & $\begin{array}{l}\text { Renal } \\
\text { Infarcts }\end{array}$ \\
\hline Perfluorobutyryl ethyl cellulose & Excellent & Excellent & $\begin{array}{l}\text { None to } \\
\text { very slight }\end{array}$ & None & Few \\
\hline $\begin{array}{l}\text { Glow discharge polymer of } \\
\text { hexamethylenedisiloxane }\end{array}$ & Excellent & Excellent & Very slight & None & Few \\
\hline $\begin{array}{l}\text { Grafted HEMA hydrogel } \\
\text { (active-vapor) } \dagger\end{array}$ & Good & $\begin{array}{l}\text { Good to } \\
\text { fair }\end{array}$ & Slight & None & Numerous \\
\hline \multirow[t]{2}{*}{$\begin{array}{l}\text { Grafted acrylamide } \\
\text { hydrogel } \ddagger\end{array}$} & Excellent & $\begin{array}{l}\text { Excellent } \\
\text { to good }\end{array}$ & $\begin{array}{c}\text { None to } \\
\text { slight }\end{array}$ & None & Few \\
\hline & Excellent & $\begin{array}{l}\text { Excellent } \\
\text { to good }\end{array}$ & $\begin{array}{l}\text { None to } \\
\text { very slight }\end{array}$ & $\begin{array}{l}\text { None to } \\
\text { slight }\end{array}$ & Few \\
\hline Polyalkylsulfone & Excellent & Good & $\begin{array}{l}\text { Very slight } \\
\text { to medium }\end{array}$ & None & $\begin{array}{c}\text { Few to } \\
\text { numerous }\end{array}$ \\
\hline LTI carbon (polished) & Excellent & Excellent & $\begin{array}{c}\text { None to } \\
\text { very slight }\end{array}$ & None & Few \\
\hline
\end{tabular}

$\dagger$ Equilibrium water uptake less than $35 \%$.
$\ddagger$ Equilibrium water uptake $60-75 \%$.

filler normally present in commercial silicone elastomers. This view is reinforced by the finding of other investigators who have reported good blood compatibility of silicone rubber free of silica filler in extracorporeal membrane oxygenators. ${ }^{28}$

Also under development are novel anisotropic block polymer laminates with directional stiffness ratios similar to those of natural tissue components of the body, especially heart valves ${ }^{40}$ This as well as other approaches that recognize the anisotropy of natural tissues should make it possible to design novel artificial leaflet heart values for eventual clinical use in conjunction with various surface treatments to achieve blood compatibility. ${ }^{41}$

\section{CONCLUSIONS}

It is imperative to understand better the events that take place at the molecular level under the rheological conditions of the physiological environment when blood contacts artificial surfaces and the natural tissue components. This information then must be applied to the synthesis and modifications of polymers and related to specific clinically useful diagnostic, surgical and therapeutic uses. It should be recognized that materials must be developed for particular biomedical applications because no single material can fulfill the functions of all requirements.

Acknowledgement-I wish to thank Ms. Andrea Keeper for the typing of the manuscript.

\section{REFERENCES}

${ }^{1}$ S. D. Bruck, Blood Compatible Synthetic Polymers-An Introduction. Charles C. Thomas, Springfield, Illinois (1974).

${ }^{2}$ S. D. Bruck, J. Biomed. Mater. Res. 6, 173 (1972).

${ }^{3}$ S. D. Bruck, Biomat. Med. Dev. Artif. Organs, 1; 79 (1973).

${ }^{4}$ S. D. Bruck, Trans. Am. Soc. Artif. Int. Organs, 18, 1 (1972).

${ }^{5}$ S. D. Bruck, S. Rabin and R. J. Ferguson, Biomat. Med. Dev. Artif. Organs, 1, 191 (1973).

${ }^{6}$ L. Vroman and A. L. Adams, J. Biomed. Mater. Res. 3, 43 (1969).

${ }^{7}$ R. C. Dutton, A. J. Webber, A. S. Johnson and R. E. Baier, J. Biomed. Mater. Res. 3, 13 (1969).

${ }^{8}$ D. J. Lyman, J. L. Brash, S. W. Chaikin, K. G. Klein and M. Carini, Trans. Am. Soc. Artif. Int. Organs, 14, 250 (1968).
${ }^{9}$ R. E. Baier, G. I. Loeb and G. T. Wallace, Fed. Proc. Fed. Am. Soc. Exp. Biol. 30, 1523 (1971).

${ }^{10}$ L. Vroman, A. L. Adams and M. Klings, Fed. Proc. Fed. Am. Soc. Exp. Biol. 30, 1494 (1971).

${ }^{11}$ Y. Nemerson and F. A. Pitlick, in Progresss in Hemostatis and Thrombosis. (Edited by T. H. Spaet), Vol. 1, p. 1. Grune \& Stratton, New York (1972).

${ }^{12}$ S. Berger and E. W. Salzman, in Progress in Hemostasis and Thrombosis (Edited by T. H. Spaet), Vol. 2, p. 273. Grune \& Stratton, New York (1974).

${ }^{13}$ R. Muggli and H. R. Baumagartner, Thrombosis Res. 3, 715 (1973) ${ }^{14}$ A. L. Copley, Microvascular Res. 8, 192 (1974).

${ }^{15}$ J. C. Bokros, L. D. LaGrange and F. J. Schoen, in Chemistry and Physics of Carbon (Edited by P. L. Walker) Vol. 9, Ch. II, p. 103. Dekker, New York (1973).

${ }^{16}$ V. L. Gott, D. E. Koepke, R. L. Dagget, W. Zarnstorff and W. P. Young, Surgery, 50, 382 (1961).

${ }^{17}$ R. I. Leininger, C. W. Cooper, R. D. Falb and G. A. Grode, Science, 152, 1625 (1966).

${ }^{18}$ R. L. Merker, L. J. Elyash, S. H. Mayhew and J. Y. C. Wang, in Proceedings of the Artificial Heart Program Conference, (Edited by R. J. Hegyeli) p. 29. Washington, U. S. Government Printing Office (1969).

${ }^{19}$ E. W. Salzman, W. G. Austen, B. J. Lipps, E. W. Merrill, E. R. Gilliland and J. Joison, Surgery, 61, 1 (1967).

${ }^{20}$ H. R. Lagergren and J. C. Eriksson, Trans. Am. Soc. Artif. Int. Organs, 17, 10 (1971).

${ }^{21}$ D. J. Lyman, J. L. Brash and K. G. Klein, in Proceedings of the Artificial Heart Program Conference, (Edited by R. J. Hegyeli) p. 113. Washington, U. S. Government Printing office (1969).

${ }^{22}$ J. L. Brash, B. K. Fritzinger and S. D. Bruck, J. Biomed. Mater. Res. 7, 313 (1973).

${ }^{23}$ J. W. Boretos and W. S. Pierce, J. Biomed. Mater. Res. 2, 121 (1968).

${ }^{24}$ R. J. Petersen and L. T. Rozelle, Ultrathin membranes for blood oxygenators, Annual Report, PB 238352, (December 1974), (available from the National Technical Information Service, Springfield, Virginia 22151).

${ }^{25}$ J. M. Ketteringham, W. M. Zapol, D. N. Gray, K. K. Stevenson, A. A. Massucco, L. L. Nelsen and D. P. Cullen, Trans. Am. Soc. Artif. Int. Organs, 19, 61 (1973).

${ }^{26}$ H. Yasuda and C. E. Lamaze, J. Appl. Polym. Sci. 17, 1533 (1973).

${ }^{27} \mathrm{H}$. Yasuda, A study of glow discharge polymerization as a means of modifying the surface of polymers, Annual Report, (January 1975), (available from the National Technical Information Service, Springfield, Virginia 22151).

${ }^{28}$ T. Kolobow, E. W. Stool, P. K. Weathersby, J. Pierce, F. 
Hayano and J. Suaudeau, Trans. Am. Soc. Artif. Int. Organs, 20, 269 (1974).

${ }^{29}$ H. Scott, P. L. Kronick and E. E. Hillman, Active-vapor grafting of hydrogels in medical prostheses, Annual Reports, PB 206499 (August 1971), PB 221846 (February 1973), and PB 230308 (January 1974), (available from the National Technical Information Service, Springfield, Virginia 22151).

${ }^{30}$ B. D. Halpern, M. K. Akkapeddi and S. L. Ledis, Polymer studies related to prosthetic cardiac materials which are non-clotting at a blood interface, Annual Reports, PB 230310 (February 1974), PB 200987 (January 1971), PB 212724 (September 1972), PB 215886 (February 1973), and PB 239882 (December 1974), (available from the National Technical Information Service, Springfield, Virginia 22151).

${ }^{31}$ A. S. Hoffman, G. Schmer, C. Harris and W. G. Kraft, Trans. Am. Soc. Artif. Int. Organs, 18, 10 (1972).

${ }^{32}$ G. T. Kwiatkowski, W. S. Creasy and D. D. Stewart, Annual Report, PB 238814 (October 1974), (available from the National Technical Information Service, Springfield, Virginia 22151).

${ }^{33}$ S. D. Bruck, J. Biomed. Mater. Res. 7, 387 (1973).

${ }^{34}$ S. D. Bruck, Abstracts, Am. Soc. Artif. Internal Organs, 21 st Annual Meeting, Vol. 4, p. 6, Washington, D. C., April 17-19, 1975.

${ }^{35}$ E. F. Leonard, S. Kochwa and R. S. Litwak, Annual Report,
(January 1975), (available from the National Technical Information Service, Springfield, Virginia 22151).

${ }^{36} \mathrm{O}$. Wichterle and D. Lim, Nature Lond., 185, 117 (1960).

${ }^{37}$ M. P. Singh and D. G. Melrose, Bio-Med. Eng. 6, 157 (1971).

${ }^{38}$ R. H. Kahn and W. E. Burkel, In Vitro, 450 (1973); refer also;

"Multiple-layered intimal linings by perfusion culture", Annual Report, PB 238752 (December 1974), (available from the National Technical Information Service, Springfield, Virginia 22151).

${ }^{39}$ Y. Imai, K. Tajima and Y. Nose, Trans. Am. Soc. Artif. Int. Organs, 17, 6 (1971); refer also: Development of blood and tissue compatible materials, Annual Report, PB 231616 (December 1973), (Available from the National Technical Information Service, Springfield, Virginia 22151).

${ }^{40}$ J. L. Kardos, C. Thies, R. E. Clark and S. F. Apostolou, Development and mechanical characterization of anisotropic polymeric biomaterials, Annual Report, (January 1975), (available from the National Technical Information Service, Springfield, Virginia 22151).

${ }^{41}$ R. E. Clark, P. L. Gould, W. M. Swanson, J. L. Kardos, H. M. Karara, J. Skelton and G. A. M. Butterworth, Proceedings, 32nd Annual Technical Conference, Soc. Plastic Engineers, 20, 734 (1974). 